\title{
Redescription of Cadrema pallida var. bilineata (de Meijere, 1904) (Diptera: Chloropidae) and its role as pollinator and carrion feeder from Indian Sunderbans
}

\author{
Sankarsan Roy ${ }^{1 *}$, Susanta Kumar Chakraborty ${ }^{2}$, \\ Panchanan Parui', Udipta Chakraborti', Olive \\ Biswas', Bulganin Mitra' $^{1}$ \\ 'Zoological Survey of India, Prani Vigyan Bhawan, M- Block, New \\ Alipore, Kolkata - 700053, India. \\ ${ }^{2}$ Department of Zoology, Vidyasagar University, Rangamati, \\ Medinipur, West Bengal - 721102, India.
}

\section{Introduction:}

Sunderbans, the UNESCO World Heritage Site is one of the largest mangrove forests in the World. This unique tidal halophytic mangrove ecosystem is also spread over the neighbouring country- Bangladesh. This ecosystem supports a variety of halophytic mangrove species and provides shelter and food to many faunal components (Chakraborty, 2011). Till date, several studies have been made on dipteran fauna from SBR which was altogether compiled by Mitra (2013). Further, Mitra et al. (2014, 2015) added some more records of the Diptera from this area. Apart from documenting the dipteran insects, we attempted here their functional contribution towards sustainability of this sensitive ecosystem.

Unfortunately, no record of any representative of the family Chloropidae from SBR has been reported yet. The present communication reports Cadrema pallida var. bilineate (de Meijere, 1904) belonging to this family for the first time from SBR, India. An attempt has also been taken to highlight the role of the species as a pollinator of mangroves.

\section{Taxonomic Account:}

The family Chloropidae is a group of acalyptrate Diptera under suborder Brachycera (Pape et al., 2011), commonly known as grass flies. These are usually very small flies (1.0 $4.0 \mathrm{~mm}$ ), rarely medium-sized $(6.0-9.0 \mathrm{~mm})$, yellow or black and appearing shiny. The wings after being developed, sometime get reduced to small disks (plates) having scantyvenation (Cherian, 2002).

Systematic Account:

Order Diptera; Suborder Brachycera; Clade Cyclorrhapha;

Infraorder Schizophora; Parvorder Acalyptratae'

Superfamily Carnoidea; Family Chloropidae

Cadrema pallidavar. bilineata (de Meijere)

1904. Cadrema pallida var. bilineata de Meijere. Dierk. 17: 113 (sex?;Hippelates).
Study Area: Bali Island, Sagar Island and Bakkhali Island, Sunderban Biosphere Reserve, India.

Coordinates: $22^{\circ} \mathrm{O} 5 \cdot 335^{\prime} \mathrm{N} \& 088^{\circ} 45.552^{\prime} \mathrm{E} ; 21^{\circ} 38.265^{\prime} \mathrm{N} \&$ $088^{\circ} 04.946^{\prime} \mathrm{E} ; 21^{\circ} 35.089^{\prime} \mathrm{N} \& 088^{\circ} 17.323^{\prime} \mathrm{E}$

Key words: Diptera, Flower visitor, Sunderban Biosphere reserve.

1989. Cadrema pallida var. bilineata: Mathis. Atoll Research Bulletin. 327:7

Type- Locality: Pasuruan, Java.

Material examined: 2exs. Bali Island, 9 no. Gheri, Sunderban, West Bengal, India, 20.iii.2015; 3exs. Sagar Island, Gangasagar, Sunderban, West Bengal, India, 19.v.2015; 1exs. Bakkhali, Kalisthan, Sunderban, West Bengal, India, 18.vi.2015; coll. B. Mitra \& party.

Re-description: Body brownish yellow, very small in size (1.6$2.0 \mathrm{~mm}$ ) (Fig.- 1a), head orange-yellow in colour except vertical triangle, eyes black, antennae yellow with dark brown arista bearing two rows of small concolorous hairs, proboscis and palpi arealsoyellow in colour.

Pronotum bears a pair of black round spots in the middle portion. Notopleural region brownish.

Thorax orange-yellow in colour with a pair of light brown longitudinal stripes, closest to lateral margins of the thorax (Fig.1b), basal half of the scutellum concolourous with a pair of convergent bristles. Post scutellum dark brown or black; wings hyaline, margin of the wings are covered with small bristles.

Abdomen brown in colour, anterior part is lighter while the posterior part of the abdomen becomes darker brown.

Legs yellowish brown with profuse yellow hairs, fore tibiae and tarsi only dark brown, mid leg uniformly yellow, hind femora robust and light yellowish in colour while the tibiae of the hind leg little darker with a stout curved black bristle at apex (Fig.- 1C).

Distribution: Widespread in the Orient and Oceania (extending to the Marquesas and south to the Pitcairn Group).

\section{Potential as Flowervisitor/ Pollinator:}

Cadrema pallida var. bilineata was noted in large numbers visiting the flowers of Excoecaria agallocha at Bakkhali and flowers of Avicennia officinalis at Bali and Sagar Islands. The frequency of visit, behavioural activities and duration spent on a single flower conf irm this species as a potential pollinator of these mangrove species.

Potential as an agent for forensic entomology:

Cadrema pallida var. bilineata is also observed in large numbers along with several other dipteran species,

*Corresponding Author: sroy.zoology@gmail.com 
viz.Chrysomya megacephala (Fabricius, 1794) of the family Calliphoridae, Musca (Musca) domestica Linnaeus, 1758 and Atherigona (Acritochaeta) orientalis Schiner, 1868 of the family Muscidae and Sarcophaga (Liosarcophaga) dux Thomson, 1869 of the family Sarcophagidae on the carcass of a dog found lying on the shorelines of the river Gomor (local name), a tributary of River Ganges. The first sighting of C.pallida var. bilineata occurred after 48 hours of the death of the host and the number of species increased within 72 hours after the death of the animal. Chrysomya megacephala (Fabricius, 1794) is observed almost in similar numbers at 48 and 72 hours of a time interval (table-1).

Table 1: Dipteran species present in different time interval from dog carcass ( $h=$ hours)

\begin{tabular}{|c|c|c|c|c|c|}
\hline \multicolumn{2}{|c|}{ S.n. Name of the species } & \multirow{2}{*}{$\begin{array}{l}\text { Family } \\
\text { Chloropidae }\end{array}$} & \multirow{2}{*}{$\frac{24 h}{X}$} & \multirow{2}{*}{$\frac{48 h}{\checkmark}$} & \multirow{2}{*}{$\frac{72 h}{\checkmark}$} \\
\hline 01 & $\begin{array}{l}\text { Cadrema pallida var. } \\
\text { bilineata }\end{array}$ & & & & \\
\hline 02 & Chrysomya megacephala & Calliphoridae & $\mathrm{X}$ & $\checkmark$ & $\checkmark$ \\
\hline 03 & Musca (Musca) domestica & Musc & $\checkmark$ & $\checkmark$ & $\mathrm{X}$ \\
\hline 04 & $\begin{array}{l}\text { Atherigona (Acritochaeta) } \\
\text { orientalis }\end{array}$ & Muscidae & $\mathrm{X}$ & $\checkmark$ & $\mathrm{X}$ \\
\hline 05 & $\begin{array}{l}\text { Sarcophaga (Liosarcophaga) } \\
\text { dux }\end{array}$ & Sarcophagida & $\mathrm{X}$ & $\checkmark$ & $\checkmark$ \\
\hline
\end{tabular}

(X-absent; $\checkmark$-Present)

\section{Discussion:}

This is the first report on the occurrence of the species $C$. pallida var. bilineata (de Meijere, 1904) and the first representative of the family Chloropidae from SBR. According to Sabrosky (1977), only two species of the genus CadremaWalker were reported from India; C.minor (de Meijere, 1908) was reported from Assam, Maharashtra, West Bengal and C. pallida var. bilineata was reported from West Bengal. This species, C. pallida var. bilineata, is known from Afro-tropical, Palearctic, Nearctic and Oriental region and is a very widely distributed species. Citation of this species was also found from several islands of the Indian Ocean and South Pacif ic Ocean.

Earlier Hinckley (1969) only reported the genus Cadrema (species name not mentioned) as flower visitor of Morinda shrubs at Tokelau atolls, territory of New Zealand in the South Pacific Ocean. This communication reports the species $C$. pallida var. bilineata as flower visitor/pollinator of the major mangrove species Excoecaria agallocha and Avicennia officinalis in Sunderbans. This species is moderately common on the beach at the high tide mark where debris had accumulated (Mathis, 1989), which also supports the present observation as an enormous number of examples are found in mangrove zones of Bali Island, Bakkhali and also near the sea beach areas of Sagar Island.

Previously, Bohart \& Gressitt (1951) in Guam recorded C. pallida var. bilineata on human excrement, cow and pig dung, dead rat, decaying molluscs, star fishes and coconut, tomato, papaya. Moreover, this species could be

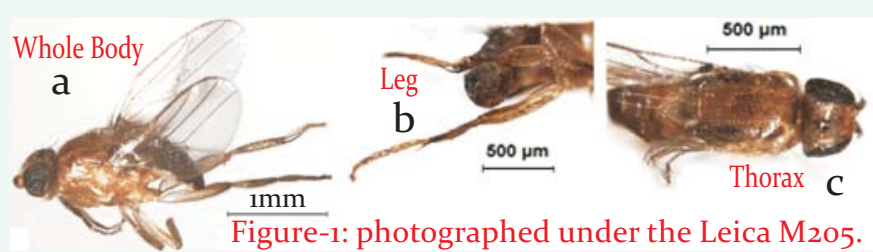

highly attracted to the decaying flesh of rats, fishes, molluscs etc. Bohart \& Gressitt (1951) have also found larvae of this species from decaying mollusc's body, rotten coconut, and pig excrement.This is the first report of this species from the carcass of a mammal from India. Therefore, this species can be considered as an important agent in forensic entomology.

Conclusively, Cadrema pallida var. bilineata has been re-described from West Bengal, India after a long time. Earlier, nothing has been mentioned about its natural history.

Acknowledgements:

Authors are grateful to Dr. Kailash Chandra, Director, Zoological Survey of India, Kolkata for giving required permission to carry out the work and encouragement. Authors are also thankful to Shri K. C. Gopi, Additional Director, Zoological Survey of India for constant support, help and guidance. Thanks are also due to Ministry of Environment, Forest and Climate Change, Government of India, for financial assistance.

\section{References:}

Bohart, G.E., Gressitt, J.L. (1951): Filth-inhabiting flies of Guam. Bull. Bishop Mus., Honolulu, 4:1-151

Chakraborty, S.K. (2011): Mangrove Ecosystem of Sundarbans, India: Biodiversity, Ecology, Threats and Conservation. In. Mangroves: Ecology, Biology and Taxonomy. James $\mathrm{N}$. Metras (Edt) (Publ. by NOVA publisher, USA). pp. 83-112.

Cherian, P.T. (2002): Fauna of India and the adjacent countries - Diptera Vol. IX. Chloropidae (Part 1), pp. 1-368 (Published-Director, ZSI, Kolkata).

Hinckley, A.D. (1969): Ecology of Terrestrial Arthropods on the Tokelau Atolls. Atoll Res. Bull., 124:1-18

Mathis, W.N. (1989): Diptera (Insecta) or true flies of the Pitcairn group (Ducie, Henderson, Oeno, and Pitcairn islands) Atoll Res. Bull., 327:1-15

Mitra, B., Mirdha, R., Parui, P. (2003): Diptera from Sagar Island, South 24 Parganas, West Bengal. Bionotes, 5 (3): 69.

Mitra, B. (2013): A synoptic retrospect on the Diptera fauna of Sunderban biosphere reserve, India. PROMMALIA,I : 56- 64

Mitra, B., Shah, S.K., Chakraborti, U., Roy, S., Biswas, O., Biswas, B., Das, S.K., Kumar, G.P. (2014): Additional records of entomofauna from Sunderban Islands, West Bengal. BIONOTES, 16(4): 134-135

Mitra, B., Parui, P., Roy, S., Biswas, O. \& Chakraborti, U. (2015): A note on Stilt-legged Flies (Diptera: Micropezidae) with the First Record of Mimegralla albimana(Doleschall, 1856) from Sunderban Biosphere Reserve, India. Entom. App. Sci. Lett., 2(2):16-19

Pape, T., Blagoderov, V. \& Mostovski, M.B. (2011): Order DIPTERA Linnaeus, 1758. In:Zhang, Z.-Q. (Ed.) Animal biodiversity: An outline of higher-level classification and survey of taxonomic richness. Zootaxa, 3148: 222-229.

Sabrosky, C.W. (1977): Family Chloropidae. In: Catalog of the Diptera of the Oriental Region, Edited by Delfinado and Hardy. The University press of Hawaii, Honolulu, vol. III, pp. 279-280. 